\title{
Research of Fuzzy Comprehensive Evaluation of the Information-based Teaching
}

\author{
Dongjing Pan \\ Department of Computer Science and Technology, Dezhou University, Dezhou 253023, China \\ E-mail: pdj1970@163.com
}

\begin{abstract}
Modern educational technology especially modern information technology brought new opportunity for the reform of class teaching, and at the same time, reasonable and effective information-based teaching evaluation method must be designed to promote information-based teaching. The article analyzes the characteristics of information-based teaching and constructs its evaluation index system. And then these factors' weight is determined by means of AHP and the fuzzy comprehensive evaluation model is applied to assess information-based teaching and validated by an example.
\end{abstract}

Keywords: Information-based teaching, Evaluation index system, Fuzzy Comprehensive Evaluation

With the rapid development of information society, the information technology such as multi-media computer and internet has permeated into every aspect of teaching and learning, and traditional education concept, education method, the aim of education and education contents have taken profound changes. Crossing time and space, large amount of information, interactivity and individual study make the classroom teaching enter information age, which makes the educators adapt to the development of times in terms of education teaching concept, textbook construction, teaching mode, teaching method, teaching evaluation and so on and explore constantly teaching mode and its construction under the new information technology environment.

The evaluation method of informationization teaching should conform to the requirements of quality education. In the teaching of informationization classroom teaching, the application of multi-media and internet changed the positions of teachers and students and education concept and teaching strategy are experiencing profound changes, which require establishing a new mode of teaching and learning. The changes of education concept inevitably caused to the corresponding changes of instructional evaluation and then the evaluation of informatiization teaching was born. How to judge the value of informationization classroom teaching and how to assess the quality of informatiation have became the problems to solve. The evaluation of informatization teaching is a kind of activity, which applied a series of evaluation technology and method to assess qualitatively or quantitatively the effect of informatization teaching according to the information-based teaching concept. It plays an important role in improving the teaching quality and prompting educational reform.

\section{The analysis and evaluation of information-based teaching}

Information-based teaching is a new teaching method which scientifically and effectively integrates information technology, information resource, information method and human resource into the contents, structure and implementation of curriculum in the process of teaching and uses information technology to finish the task of teaching. Informatization education brought great shock to traditional teaching mode which mainly focuses on the instruction and teachers and put forward the serious challenge to teachers.

Based on the environment of information-based teaching, the teacher's role has new characteristics. The development of information technology provides fairly endless information for each person. How to make each student grow healthily in the wave of information and what kind of talents school should train, are inevitable problems which the teaching must solve in information times. The rapid knowledge renewal and the advent of learning society require that instruction must be directed to develop the personality and improve human's overall quality. Education is no longer merely pure book knowledge and skills and finishing assignments and taking exams. Education will change profoundly your own goals and functions and then become the assistant of individual all-round and lifelong growth and also the intensive instructor for personal choice and development in information society.

The new characteristics of information-based teaching endow teaching evaluation with new contents. In the subject knowledge and teaching ability, it requires teachers must master new information technology; in the classroom teaching, they could make good use of information technology to interact all-roundly with students in and out of class so as to provide individual teaching for students and teach students according to their aptitude. For example, teachers communicate with their students by BBS, online $\mathrm{Q} / \mathrm{A}$ and so on so as to realize 
target-oriented teaching. Teachers have to do well in guiding students to take advantages of information resource. The new evaluation content not only puts forward new guidelines under the environment of information for teachers, but also prompts teachers to convert to life-long learner.

Here are the principles which the information-based teaching should follow below:

1) Universality: Teaching evaluation fully embodies the aim of education and instruction so evaluation indictors should start from the whole, which not only consider every stage in the process of instruction but also classify the performances of each evaluation indictor and set reasonable weight so as to highlight its impact.

2) Scientification: If the evaluation design accords with the basic principles of pedagogy and psychology, the design of indicators, evaluation methods and conclusions should be scientific. Evaluation methods should combine qualitative and quantitative in order that the conclusion has higher reliability and comparable.

3) Practicability: evaluation indictors should clear and specific and the evaluation methods are simple and feasible, which is convenient for teachers to use and accept.

4) Emphasis on study principle: The aim of evaluation is to urge learners to study effectively and improve the effectiveness of teaching. Therefore, in the design of evaluation criterion it should attach importance to how to teach and learn.

\section{The establishment of information-based teaching fuzzy evaluation method}

\subsection{Constructing the evaluation index system}

Constructing the scientific, reasonable and feasible evaluation index system is the premise and basis for evaluating the information-based teaching right. The object to teaching evaluation is the process of teaching activity. The construction of evaluation index system should obey the principles of universality, scientification and emphasis on study. The two-class index systems are constructed referring to some information-based teaching evaluation criterions and asking for the associated expertise through analyzing. The first class indexes are teachers' qualities, teaching goals, teaching processes, teaching methods, teaching effects. The first class index also determines the second class one and the information-based teaching evaluation index system is shown in figure 1:

\subsection{The determination of comment set}

The comment set $V=\left\{v_{1}, v_{2}, \cdots, v_{m}\right\}$ has to be determined. The comment set is the collection of all kinds of comment results that the estimator makes on the evaluation subject. The commenting criterions of the indexes can be divided into 4 classes \{excellent, good, moderate, bad\} according to the actual characteristics and computational complexity of informationization teaching and the characteristics of human beings' thought, namely $V=\left\{v_{1}\left(\right.\right.$ excellent 90 100), $v_{2}(\operatorname{good} 75 \sim 90), v_{3}(\operatorname{moderate} 60 \sim 75), v_{4}($ bad 60 below) $\}$.

\section{Calculating each index's weight by means of AHP}

The basic steps for determining weight by AHP are:

3.1 establishing the matrix for comparing weight and supposing the weight of $n$ evaluation factors known, the $n \times n$ matrix can be expressed as:

$A=\left[\begin{array}{cccc}a_{11} & a_{12} & \cdots & a_{1 n} \\ a_{21} & a_{22} & \cdots & a_{2 n} \\ & & \vdots & \\ a_{n 1} & a_{n 2} & \cdots & a_{n n}\end{array}\right]$

$a_{i j}$ is the rate of importance of index $a_{i}$ relative to index $a_{j}$, and $a_{i i}=1, a_{i j}=1 / a_{j i}$.

How to mark the importance of $a_{i}$ relative to $a_{j}$ concretely? Saaty proposed the scale method for 1-9 rate according to the psychological research result that most people merely compare $7 \pm 2$ objects at one time (shown in table 1)

3.2 This paper applies sum and product method to calculate the weight of judging matrix: normalized the judging matrix according to lines; sum the normalized matrix according to rows; normalized the vectors to obtain the weight vector and the formula can be expressed as: 


$$
w_{i}=\frac{1}{n} \sum_{j=1}^{n} \frac{a_{i j}}{\sum_{i=1}^{n} a_{i j}} \quad(i, j=1,2, \cdots, n)
$$

3.3 Calculating the coherence rate to judge the ratio that the coherence index CI compares to the average random coherence index $\mathrm{RI}$ is called random coherence rate, denoted by $\mathrm{CR}$. When $\mathrm{CR}=\mathrm{CI} / \mathrm{RI} \leq 0.1$, one has to judge the matrix bearing the content coherence, otherwise the judgment matrix has to be adjusted and the grade has to be remodified to make the matrix possess the content coherence. The $\mathrm{CI}$ is the coherence index and defined as: $C I=\frac{\lambda_{\max }-n}{n-1}, \lambda_{\max }$ is the maximal feature of judgment matrix, defined as $\lambda_{\max }=\sum_{i=1}^{n} \frac{(A w)_{i}}{n w_{i}}$. The values of average random coherence index RI is given in table 2 .

All the indexes are evaluated in a group including two ones by the associated teaching experts according to AHP. The calculations and the tested coherence results of the evaluation factors' weight in the indexes system are shown in table 3 8.

\section{The multistage fuzzy evaluation}

When the evaluation factor collections $U$ and the comment collections $V$ are determined, the fuzzy relation matrix R can be built between the two collections for the special index system:

$R=\left[\begin{array}{cccc}r_{11} & r_{12} & \cdots & r_{1 m} \\ r_{21} & r_{22} & \cdots & r_{2 m} \\ & & \vdots & \\ r_{n 1} & r_{n 2} & \cdots & r_{n m}\end{array}\right]$, in that $r_{i j}$ denotes the subjection degree of index $u_{i}$ regarded as $v_{j}$ and the subjection degree is defined $r_{i, j}=\frac{\text { number of peopl e whose i ndex } u_{i} \text { is regarded as grade } v_{j}}{\text { tot al number of peopl e examined }}$, so the integrative judgement on the index can be obtained: $B=A \circ R=\left(b_{1}, b_{2}, b_{3}, \cdots, b_{n}\right)$, in which the integrative operator $\circ$ of weight vector $A$ and fuzzy matrix $R$ applies the weighted average type, namely $M(\bullet, \oplus)$.

\section{Real examples and analyzing results}

One teacher's informationization teaching is evaluated making use of the above method. All the indexes of this teacher are evaluated by ten associated experts and the evaluation results are shown in table 9 .

The fuzzy judgment matrixes $R_{1} \sim R_{5}$ of the second class indexes can be obtained according to the above table. The evaluation vectors of the second class indexes can be calculated according to $B=A \circ R$ and the results are:

$$
\begin{aligned}
& B_{1}=(0.1613,0.4,0.3443,0.0944) \\
& B_{2}=(0.1,0.5333,0.3334,0.0333) \\
& B_{3}=(0.16,0.4,0.38,0.06) \\
& B_{4}=(0.2667,0.3667,0.3,0.0666) \\
& B_{5}=(0.2539,0.3,0.3297,0.1164)
\end{aligned}
$$

The integrative judgment result of the second class indexes is regarded as the fuzzy matrix for the first class judgment and the fuzzy judgment matrix for evaluating the information-based teaching is obtained as follows: 


$$
R=\left[\begin{array}{cccc}
0.1613 & 0.4 & 0.3443 & 0.0944 \\
0.1 & 0.5333 & 0.3334 & 0.0333 \\
0.16 & 0.4 & 0.38 & 0.06 \\
0.2667 & 0.3667 & 0.3 & 0.0666 \\
0.2539 & 0.3 & 0.3297 & 0.1164
\end{array}\right]
$$

So the judgment vector for the first class index is:

$$
B=A \circ R=(0.1884,0.3883,0.3399,0.0834)
$$

It is found that the final comment on this teacher is good $\{75 \sim 90\}$. The comment collection is valued according to each grade: excellent (95), good(82), moderate(67), bad(40). More intuitionistic evaluation results in centesimal grade can be got through the transformation of $B$ using the formula as follows: $a=\left(\sum_{i=1}^{m} b_{i}^{2} a_{i}\right) / \sum_{i=1}^{m} b_{i}^{2}$, in which $a_{1}=95, a_{2}=82, a_{3}=67, a_{4}=40$, to obtain $a=76.936$, so the final evaluation result for this teacher is good.

\section{Conclusions}

There still more influence factors about teaching evaluation in the information environment and the weight value need to be decided according to realistic circumstances. The article takes fuzzy comprehensive evaluation on the information-based teaching in the hope that we could provide one evaluation method combined qualitative with quantitative so as to prompt the development information-based teaching.

\section{References}

Bie, Wenqun \& Niu, Xingfeng. (2007). Research of fuzzy comprehensive evaluation model about network curriculum. Information-based education in China. 2007(11): PP. 20-23.

Li, Qun. (2005). Research of uncertain mathematical methods and its application in social science. Beijing: China Social Sciences Press.

Zheng, Yaoguang \& Su, Jianyi. (2006). The discussion about the information-based classroom teaching evaluation criterion. Electrified education in elementary and secondary school. 2006(4):25-27.

Zhou, Ronggang. (2007). Research of fuzzy comprehensive evaluation about the quality of IT products user experience. Computer engineering and applications. 43(31): PP. 102-105.

Zhou, Wenjin. (2005). Information-based teaching's evaluation. Forum on Contemporary Education. 2005(20):19-20.

Table 1.

\begin{tabular}{|l|l|}
\hline Scale & The meaning of comparing the important degree \\
\hline 1 & Equally important \\
3 & Ratherish important \\
5 & Obviously important \\
7 & Intensely important \\
9 & Extremely important \\
$2,4,6,8$ & The important degree lies between the above important degrees \\
\hline
\end{tabular}

Table 2.

\begin{tabular}{|c|c|c|c|c|c|c|c|c|c|c|}
\hline $\begin{array}{c}\text { Matrix order } \\
\mathrm{n}\end{array}$ & 1 & 2 & 3 & 4 & 5 & 6 & 7 & 8 & 9 & 10 \\
\hline RI values & 0 & 0 & 0.58 & 0.90 & 1.12 & 1.24 & 1.32 & 1.41 & 1.45 & 1.49 \\
\hline
\end{tabular}


Table 3. The judgment matrix and weight of teachers' qualities evaluation indexes

\begin{tabular}{|c|c|c|c|c|}
\hline & $\begin{array}{c}\text { Appetency and } \\
\text { emergency force } \\
\text { in classes }\end{array}$ & Language & $\begin{array}{c}\text { Information-based } \\
\text { teaching technology }\end{array}$ & weight \\
\hline $\begin{array}{c}\text { Appetency and } \\
\text { emergency force in } \\
\text { classes }\end{array}$ & 1 & $1 / 2$ & $1 / 3$ & 0.170 \\
\hline Language & 2 & 1 & 1 & 0.387 \\
\hline $\begin{array}{c}\text { Information-based } \\
\text { teaching technology }\end{array}$ & 3 & 1 & 1 & 0.443 \\
$\lambda_{\max }=3.018$ CI $=0.009 \quad \mathrm{CR}=0.016$
\end{tabular}

Table 4. The judgment matrix and weight of teaching goals evaluation indexes

\begin{tabular}{|c|c|c|c|}
\hline & $\begin{array}{c}\text { Definite teaching } \\
\text { goals and intense } \\
\text { hierarchy }\end{array}$ & $\begin{array}{c}\text { Inducting students to use } \\
\text { information technology } \\
\text { effectively }\end{array}$ & weight \\
\hline $\begin{array}{c}\text { Definite teaching } \\
\text { goals and intense } \\
\text { hierarchy }\end{array}$ & 1 & 2 & 0.667 \\
\hline $\begin{array}{c}\text { Inducting students to } \\
\text { use information } \\
\text { technology effectively }\end{array}$ & $1 / 2$ & 1 & 0.333 \\
$\lambda_{\max }=2, \mathrm{CI}=0$
\end{tabular}

Table 5. The judgment matrix and weight of teaching processes evaluation indexes

\begin{tabular}{|c|c|c|c|c|}
\hline & $\begin{array}{l}\text { Focusing on } \\
\text { students and } \\
\text { inducting them to } \\
\text { explore }\end{array}$ & $\begin{array}{c}\text { Using } \\
\text { information } \\
\text { technology and } \\
\text { dealing with } \\
\text { teaching } \\
\text { resources } \\
\text { reasonably }\end{array}$ & $\begin{array}{l}\text { Making using of } \\
\text { information } \\
\text { technology to } \\
\text { interact with } \\
\text { students }\end{array}$ & weight \\
\hline $\begin{array}{c}\text { Focusing on } \\
\text { students and } \\
\text { inducting them to } \\
\text { explore }\end{array}$ & 1 & $1 / 2$ & $1 / 2$ & 0.2 \\
\hline $\begin{array}{l}\text { Using information } \\
\text { technology and } \\
\text { dealing with } \\
\text { teaching resources } \\
\text { reasonably }\end{array}$ & 2 & 1 & 1 & 0.4 \\
\hline $\begin{array}{l}\text { Making using of } \\
\text { information } \\
\text { technology to } \\
\text { interact with } \\
\text { students }\end{array}$ & 2 & 1 & 1 & 0.4 \\
\hline
\end{tabular}


Table 6 . The judgment matrix and weight of teaching methods evaluation indexes

\begin{tabular}{|c|c|c|c|}
\hline & $\begin{array}{c}\text { Exhibiting the development of } \\
\text { knowledge according to } \\
\text { different classes }\end{array}$ & $\begin{array}{c}\text { Teaching students according } \\
\text { to their aptitude and dealing } \\
\text { with the relationship between } \\
\text { principal part and dominance } \\
\text { appropriately }\end{array}$ & weight \\
\hline $\begin{array}{c}\text { Exhibiting the } \\
\text { development of } \\
\text { knowledge } \\
\text { according to } \\
\text { different classes }\end{array}$ & 1 & 2 & 0.667 \\
\hline $\begin{array}{c}\text { Teaching students } \\
\text { according to their } \\
\text { aptitude and dealing } \\
\text { with the relationship } \\
\text { between principal } \\
\text { part and dominance } \\
\text { appropriately }\end{array}$ & $1 / 2$ & 1 & 0.333 \\
\hline
\end{tabular}

$\lambda_{\max }=2, \mathrm{CI}=0$

Table 7. The judgment matrix and weight of teaching effects evaluation indexes

\begin{tabular}{|c|c|c|c|c|}
\hline & $\begin{array}{l}\text { Advancing the } \\
\text { transformation of } \\
\text { acknowledge to } \\
\text { accomplish the } \\
\text { course subjects }\end{array}$ & $\begin{array}{l}\text { Cultivating the } \\
\text { information } \\
\text { qualities, innovating } \\
\text { inspirits and } \\
\text { practicing abilities } \\
\text { for students }\end{array}$ & $\begin{array}{l}\text { Promoting students } \\
\text { to study initiatively } \\
\text { and allodium }\end{array}$ & weight \\
\hline $\begin{array}{l}\text { Advancing the } \\
\text { transformation of } \\
\text { acknowledge to } \\
\text { accomplish the } \\
\text { course subjects }\end{array}$ & 1 & 2 & 3 & 0.539 \\
\hline $\begin{array}{l}\text { Cultivating the } \\
\text { information } \\
\text { qualities, } \\
\text { innovating } \\
\text { inspirits and } \\
\text { practicing } \\
\text { abilities for } \\
\text { students }\end{array}$ & $1 / 2$ & 1 & 2 & 0.297 \\
\hline $\begin{array}{c}\text { Promoting } \\
\text { students to study } \\
\text { initiatively and } \\
\text { allodium }\end{array}$ & $1 / 3$ & $1 / 2$ & 1 & 0.164 \\
\hline
\end{tabular}


Table 8 . The judgment matrix and weight of information-based teaching indexes

\begin{tabular}{|c|c|c|c|c|c|c|}
\hline & $\begin{array}{c}\text { teachers' } \\
\text { qualities }\end{array}$ & $\begin{array}{c}\text { teaching } \\
\text { goals }\end{array}$ & $\begin{array}{c}\text { teaching } \\
\text { processes }\end{array}$ & $\begin{array}{c}\text { teaching } \\
\text { methods }\end{array}$ & $\begin{array}{c}\text { teaching } \\
\text { effects }\end{array}$ & weight \\
\hline $\begin{array}{c}\text { teachers' } \\
\text { qualities }\end{array}$ & 1 & 2 & 2 & 3 & 1 & 0.297 \\
\hline $\begin{array}{c}\text { teaching } \\
\text { goals }\end{array}$ & $1 / 2$ & 1 & 1 & 2 & $1 / 2$ & 0.158 \\
\hline $\begin{array}{c}\text { teaching } \\
\text { processes }\end{array}$ & $1 / 2$ & 1 & 1 & 2 & $1 / 2$ & 0.158 \\
\hline $\begin{array}{c}\text { teaching } \\
\text { methods }\end{array}$ & $1 / 3$ & $1 / 2$ & $1 / 2$ & 1 & $1 / 3$ & 0.089 \\
\hline $\begin{array}{c}\text { teaching } \\
\text { effects }\end{array}$ & 1 & 2 & 2 & 3 & 1 & 0.298 \\
\hline
\end{tabular}

$\lambda_{\max }=5.013 \quad \mathrm{CI}=0.003 \quad \mathrm{CR}=0.003$

Table 9.

\begin{tabular}{|c|c|c|c|c|c|c|}
\hline $\begin{array}{l}\text { The first } \\
\text { class } \\
\text { indexes }\end{array}$ & The second class indexes & excellent & good & moderate & bad & total \\
\hline \multirow{3}{*}{$\begin{array}{l}\text { teachers' } \\
\text { qualities }\end{array}$} & $\begin{array}{c}\text { Appetency and emergency force in } \\
\text { classes }\end{array}$ & 2 & 4 & 3 & 1 & 10 \\
\hline & Language & 1 & 4 & 3 & 2 & 10 \\
\hline & $\begin{array}{l}\text { Information-based teaching } \\
\text { technology }\end{array}$ & 2 & 4 & 4 & 0 & 10 \\
\hline \multirow{2}{*}{$\begin{array}{l}\text { teaching } \\
\text { goals }\end{array}$} & $\begin{array}{l}\text { Definite teaching goals and } \\
\text { intense hierarchy }\end{array}$ & 1 & 5 & 4 & 0 & 10 \\
\hline & $\begin{array}{l}\text { Inducting students to use } \\
\text { information technology effectively }\end{array}$ & 1 & 6 & 2 & 1 & 10 \\
\hline \multirow{3}{*}{$\begin{array}{l}\text { teaching } \\
\text { processes }\end{array}$} & $\begin{array}{l}\text { Focusing on students and } \\
\text { inducting them to explore }\end{array}$ & 2 & 4 & 3 & 1 & 10 \\
\hline & $\begin{array}{c}\text { Using information technology and } \\
\text { dealing with teaching resources } \\
\text { reasonably }\end{array}$ & 2 & 4 & 4 & 0 & 10 \\
\hline & $\begin{array}{c}\text { Making using of information } \\
\text { technology to interact with } \\
\text { students }\end{array}$ & 1 & 4 & 4 & 1 & 10 \\
\hline \multirow{2}{*}{$\begin{array}{l}\text { teaching } \\
\text { methods }\end{array}$} & $\begin{array}{c}\text { Exhibiting the development of } \\
\text { knowledge according to different } \\
\text { classes }\end{array}$ & 3 & 4 & 3 & 0 & 10 \\
\hline & $\begin{array}{l}\text { Teaching students according to } \\
\text { their aptitude and dealing with the } \\
\text { relationship between principal part } \\
\text { and dominance appropriately }\end{array}$ & 2 & 3 & 3 & 2 & 10 \\
\hline \multirow{3}{*}{$\begin{array}{l}\text { teaching } \\
\text { effects }\end{array}$} & $\begin{array}{l}\text { Advancing the transformation of } \\
\text { acknowledge to accomplish the } \\
\text { course subjects }\end{array}$ & 3 & 3 & 3 & 1 & 10 \\
\hline & $\begin{array}{l}\text { Cultivating the information } \\
\text { qualities, innovating inspirits and } \\
\text { practicing abilities for students }\end{array}$ & 2 & 3 & 4 & 1 & 10 \\
\hline & $\begin{array}{l}\text { Promoting students to study } \\
\text { initiatively and allodium }\end{array}$ & 2 & 3 & 3 & 2 & 10 \\
\hline
\end{tabular}




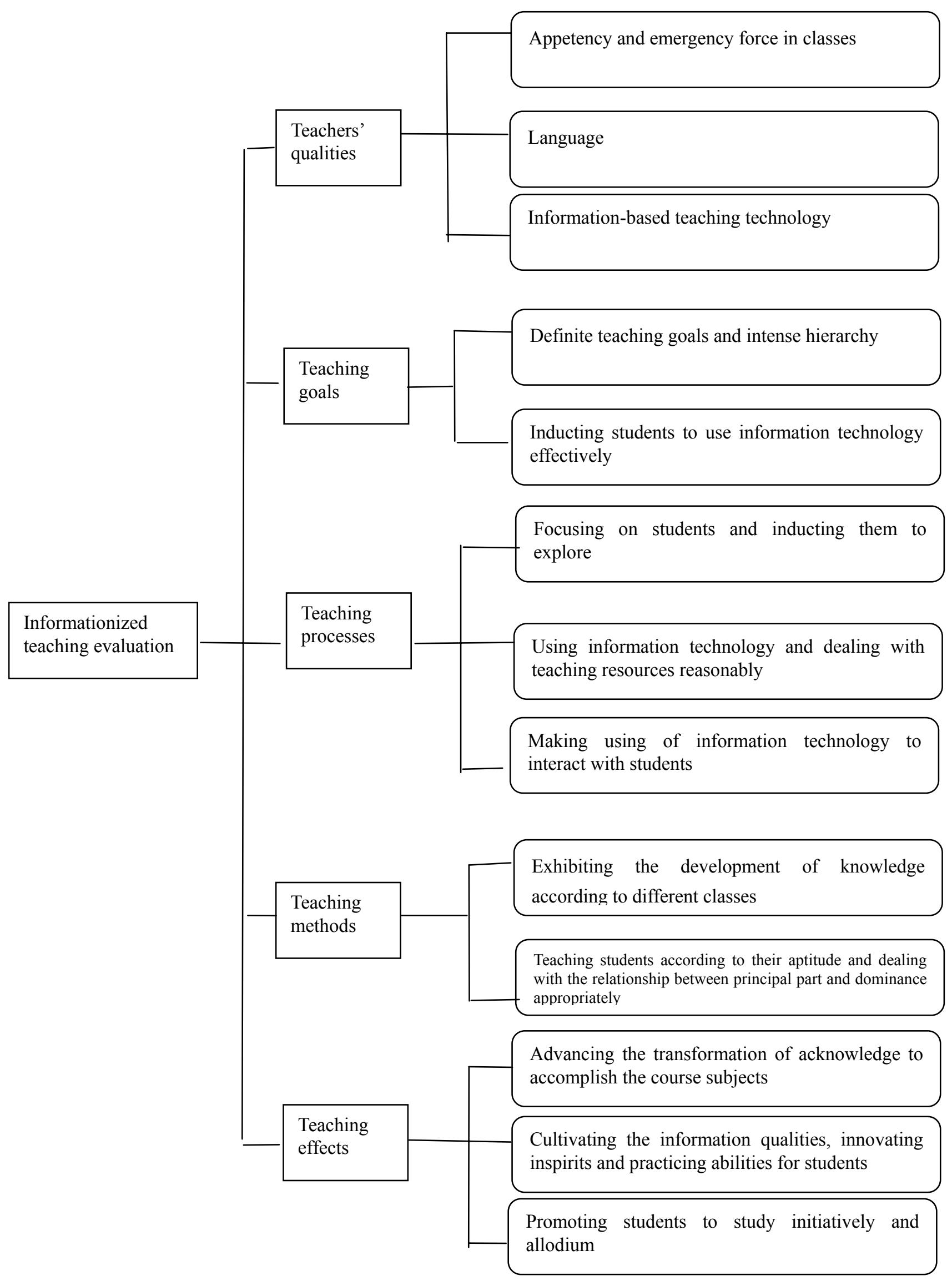

Figure 1. The indictors of informationized teaching evaluation 